\title{
Gaceta Médica de México in SARS-CoV-2 pandemic times
}

\section{Gaceta Médica de México en tiempos de pandemia por SARS-CoV-2}

\author{
Alejandro Treviño-Becerra, Francisco Espinosa-Larrañaga, ${ }^{*}$ Miguel Cruz, \\ Martha Eugenia Rodríguez-Pérez \\ Academia Nacional de Medicina, Gaceta Médica de México, Mexico City, Mexico
}

December 2019 ended with the identification and development of an atypical pneumonia epidemic caused by an unknown pathogen in Wuhan, China. At the dawn of 2020, at first week, on January 7 , the causative agent was isolated in bronchial lavage samples from a critically ill patient. Five days later, on January 12, the Chinese health authorities made the whole genome sequence of a new strain of the Coronaviridae family public: SARS-CoV-2, among whose relevant characteristics a high mortality rate stood out, as a consequence of the development of acute respiratory failure, and easy transmission.

The Gaceta Médica de México editors identified the relevance this epidemic would have for Mexico and the world, initially localized only in a region of China, and therefore we consider it of great importance to inform and alert our readers about this health problem. With that purpose, we invited experts in the field of epidemiology and public health to write two articles: an editorial, with the purpose to alert, and a review, intended to inform with updated data up to that moment, the third week of January. The authors responded with opportuneness and professionalism, and on February 5 they uploaded their documents to Gaceta Médica de México editorial management platform; both were published in the journal, in number 2 (March-April) of volume 156 of current year. Given the priority of the topic, carrying out the online preprint publication was decided, for which the publishing company Permanyer was asked to carry out the necessary instrumentation and technical changes to the Gaceta website.
Since the publication of these first articles, documents related to SARS-CoV-2 biological characteristics, transmission mechanism, clinical presentation, treatment proposals for the now COVID-19 pandemic started spontaneously arriving, mainly review articles and letters to the editor. Subsequently, articles were received on specific topics such as SARS-CoV2 neurological alterations and hematological manifestations, as well as the consequences of the pandemic on medical education.

The SARS-CoV2-related works received required a fast and reliable peer-review process, for which a group of committed reviewers was formed who took on the task of reviewing and evaluating the texts, as well as issuing a response within a week of reception of the manuscript.

By June 30 cutoff, between May and June, on average, one document per day had been received on the subject, i.e., approximately 60 , out of which $60 \%$ were rejected. The accepted works (40\%) covered $50 \%$ of number 3 contents and practically $100 \%$ of volume 156 numbers 4 and 5 .

Given the economic limitations the National Academy of Medicine of Mexico is going through, there is no possibility of doubling the number of pages of each regular issue, neither is there for publishing one or two supplements. That is our limit, which has resulted in works related to topics other than SARS-CoV-2 being scheduled for publication in the longer term.

The SARS-CoV-2 pandemic is not over and articles of national and international origin on the virus and
Correspondence:

${ }^{*}$ Francisco Espinosa-Larrañaga

E-mail: coeditor.gmm @ anmm.org.mx

0016-3813/O 2020 Academia Nacional de Medicina de México, A.C.. Published by Permanyer. This is an open access article under the CC BY-NC-ND license (http://creativecommons.org/licenses/by-nc-nd/4.0/).

Gac Med Mex. 2020;156:259-260

Contents available at PubMed

www.gacetamedicademexico.com
Date of reception: 21-07-2020

Date of acceptance: 22-07-2020 
the disease it produces continue to arrive to Gaceta Médica de México, which has met the challenge and keeps the publication open to those who have recognized their professional responsibility and analyze the information and generously communicate their experiences to other health professionals.
We appreciate the support of the reviewers and the trust of the authors, for considering Gaceta as an instrument for dissemination of this unique medical experience for the generation of professionals who are living it through. We reiterate that our commitment is to the dissemination of medical knowledge. 